\title{
DOKTRIN DAN HUKUM EKONOMI ISLAM
}

\author{
Nofialdi \\ Institut Agama Islam Negeri Batusangkar \\ e-mail: nofialdi@iainbatusangkar.ac.id
}

\begin{abstract}
Islamic economic studies can be seen from two perspectives, namely as doctrine and as law. As an Islamic economic doctrine, it can be seen as a part of worship that must be obeyed because it is taken for granted. Meanwhile, as law, Islamic economics is seen as a muamalah problem that opens up opportunities for legal change.
\end{abstract}

Keywords: Doktrin, Hukum, Ekonomi Islam

\section{PENDAHULUAN}

Keruntuhan sistem ekonomi sosialis di akhir dasawarsa 80-an memberikan peluang untuk bercokolnya hegemoni kapitalis. Namun dalam kenyataanya sistem kapitalis juga menunju ke arah kehancuran, seiring dengan krisis global yang belum menunjukan tren membaik sampai saat ini. Sehingga banyak juga pihak yang berpendapat sistem kapitalis ini tinggal menunggu waktu kehancuran sebagaimana halnya sistem sosialis. Dalam kondisi inilah diyakini bahwa sistem perekonomian Islam sebagai alternative jawaban dalam mengahadapi krisis global yang melanda dunia saat ini.

Implikasi lebih jauh, ssstem ekonomi Islam diyakini memberikan jawaban memadai dalam menghadapi kelemahan dan kekurangan kedua system yang telah ada. Karena sistem ini berpijak pada asas keadilan dan kemanusiaan. Oleh karenanya, sistem ini bersifat universal, tanpa melihat batas-batas etnis, ras, geografis, bahkan agama. Perkembangan ekonomi Islam di Indonesia dalam beberapa tahun terkahir ini, baik pada tataran teoritis-konseptual (sebagai wacana akademik) maupun pada tataran praktis (khususnya di lembaga keuangan bank dan lembaga keuangan non-bank), sangat pesat. Perkembangan ini tentu saja sangat menggembirakan, karena ini merupakan cerminan dari semakin meningkatnya kesadaran umat Islam dalam menjalankan syariat Islam. Hal ini konsekuensi dari pemahaman bahwa ekonomi Islam bukan hanya sekedar konsepsi. Ia merupakan hasil suatu proses transformasi nilai-nilai Islam yang membentuk kerangka serta perangkat kelembagaan dan 
pranata ekonomi yang hidup dan berproses dalam kehidupan masyarakat. Adanya konsep pemikiran dan organisasi-organisasi yang dibentuk atas nama sistem ini sudah tentu bisa dinilai sebagai model dan awal pertumbuhannya. Tapi ia masih membutuhkan model-model banyak lagi, agar membentuk kesatuan yang lebih terpadu serta memiliki daya kemampuan untuk menghasilkan atau darinya dapat ditarik kesimpulan-kesimpulan yang dapat diuji dalam penelitian dan praktek

Islam memiliki sistem ekonomi yang secara fundamental berbeda dari sistem-sistem yang tengah berjalan. Ia memiliki akar dalam syariat yang membentuk pandangan dunia sekaligus sasaran-sasaran dan startegi (maqashid asy-syari'ah) yang berbeda dari sistem-sistem sekular yang menguasai dunia hari ini. Sasaransasaran (yang dikehendaki) Islam secara mendasar bukan materiil. Mereka didasarkan atas konsepkonsep Islam sendiri tentang kebahagiaan manusia (falah) dan kehidupan yang baik (hayatan thayyibah) yang sangat menekankan aspek persaudaraan (ukhuwah), keadilan sosio-ekonomi dan pemenuhan kebutuhan-kebutuhan spiritual umat manusia. Ini disebabkan karena adanya kepercayaan bahwa umat manusia memiliki kedudukan yang sama sebagai khalifah Allah dimuka bumi dan sekaligus sebagai hamba-Nya, yang tidak akan dapat merasakan kebahagiaan dan ketenangan batin kecuali jika kebahagiaan sejati telah dicapai melalui pemenuhan kebutuhan-kebutuhan materiil dan spiritual. ( M.Umer Chapra, 2000: 7)

Sebagian kalangan berpendapat bahwa antara ekonomi Islam dengan ekonomi konvesional, jika dihadaphadapkan secara dikotomisantagonistik, tidak mungkin dikompromikan, karena didasari kepada pandangan yang berbeda. Ilmu ekonomi kovensional bersifat positivistik, karena menegasikan peran Tuhan dalam bangunan ekonominya. Sementara ekonomi Islam dibangun atas prinsip-prinsip religius, yang tidak mungkin lepas dari peran Tuhan dalam memberikan garis-garis demarkasi yang memisahkan antara yang hak dengan yang batil.

Hanya saja dalam tataran praksis masih ditemukan beberapa kekurangan dan kelemahan, baik dari segi konsep maupun aplikasi. Misalnya konsepsi yang mendasari bangunan ekonomi apakah bagian dari doktrin Islam atau bagian dari kegiatan muamalah manusia yang bersifat duniawi. Tulisan ini akan mencoba melihat kedua aspek ini, untuk kemudian dapat didudukan sehingga mampu mengeliminir 
ketumpangtindihan di antara kedua konsepsi tersebut.

EKONOMI ISLAM: ANTARA DOKTRIN DAN HUKUM

Pertanyaan mendasar yang penting untuk diajukan adalah apakah persoalan Ekonomi Islam itu dipandang sebagai doktrin Islam, sehingga bersifat baku, kaku, immutable, untuk kemudian dilekatkan padanya sifat abadi dan menutup diri dari berbagai macam perubahan. Atau dipandang sebagai bagian dari ketentuan atau hukum Islam yang relatif bersifat fleksibel yang membuka ruang perubahan.

Untuk menjawab pesoalan ini maka perlu dipahami bahwa hukumhukum syara' (syari'ah) itu terbagi dua kategori, yaitu al-tsabit (tetap) dan al-mutaghayyir (berubah). Al-Tsabit terkait dengan persoalan keyakinan (teologi) yang didasarkan kepada dalil yang qath'iy, sehingga menafikan perbedaan (ikhtilaf) dan menutup diri dari berbagai kemungkinan terjadinya perubahan. Sedangkan mughayyir merupakan hasil dari istinbat hukum berdasarkan nas-nas yang bersifat zanniy atau dalil-dalil yang diperselisihkan dan dibangun atas dasar kebutuhan dan kemaslahatan manusia serta tradisi (al-urf). (Nazir Hammad, 2001: 12)

Prinsip dasar dalam lapangan ibadah adalah berdasarkan kepada ketentuan syara', baik dalam bentuk perintah, larangan atau pembolehan. (Nazir Hammad, 2001: 13) Artinya seseorang dilarang melakukan ibadah, kecuali ada nas (al-Qur'an dan Sunnah) yang mewajibkan atau mengharamkannya.

Sedang untuk persoalan selain ibadah secara umum dan persoalan mu'amalah secara khusus maka prinsip dasarnya adalah boleh (mubah), sampai ada dalil yang melarang atau mengharamkannya. (Nazir Hammad, 2001: 13-14) Sedang dalam literatur klasik dalam berbagai karya ulama, utamanya yang berafiliasi kepada empat mazhab hukum sunni, terlihat bahwa persoalan harta benda dan aktifitas perdagangan dengan berbagai perniknya masuk dalam lingkup mu'amalah yang bersifat rationable. Sehingga sangat membuka diri untuk terjadi perubahan dan pengembangan jika situasi dan kondisi manusia menuntut untuk terjadinya perubahan.

Prinsip perubahan dalam hukum Islam dilandasi oleh realitas faktual, di mana teks-teks hukum terbatas, sedangkan prolematika umat yang menuntut penyelesaian senantiasa terjadi dan tak pernah berakhir. Sehingga setiap persoalan tersebut harus dicarikan penyelesaiannya melalui perluasan hukum terhadap bangunan teks yang bersifat terbatas tersebut.

Doktrin dan Hukum Ekonomi Islam | 13 
Atas asumsi ini sangat sulit untuk mengatakan bahwa ekonomi Islam merupakan bagian doktrin Islam yang bersifat kaku. Hemat penulis, kegiatan ekonomi Islam dapat dilihat dari dua sudut pandang, yaitu sudut pandang akhlak dan sudut pandang hukum. Dari sudut pandang akhlak akan melahirkan prinsip-prinsip atau nilai-nilai dasar ekomi Islam dan dari sudut pandang hukum akan melahirkan hukum ekonomi Islam.

\section{NILAI-NILAI DASAR EKONOMI ISLAM}

Nilai-nilai dasar ini diistilahkan juga oleh sebagian kalangan dengan istilah prinsip-prinsip dan menjadi dasar inspirasi untuk membangun teori-teori ekonomi islami.

\section{Tauhid (Keesaan Tuhan)}

Dalam Islam, segala sesuatu yang ada tidak diciptakan dengan siasia, tetapi memiliki tujuan. (Q.S. 23: 115) Tujuan diciptakan manusia adalah untuk beribadah kepada-Nya. (Q.S. 51: 56) Karena itu segala aktivitas manusia dalam hubungannya dengan alam (sumber daya) dan manusia (mu'amalah) dibingkai dengan kerangka hubungan dengan Allah. Karena kepada-Nya kita akan mempertanggungjawabkan segala perbuatan kita, termasuk aktivitas ekonomi dan bisnis. (Adiwarman A. Karim, 2008: 35; 'Abd al-Hamid Barahimi, 1997: 23-24)

\section{'Adl (Keadilan)}

Dalam banyak ayat, Allah memerintahkan manusia untuk berbuat adil. (Q.S. 49:9) Dalam Islan adil didefenisikan sebagai "tidak menzalimi dan tidal dizalimi". Implikasi dari nilai ini adalah bahwa pelaku ekonomi tidak dibolehkan untuk mengejar keuntungan pribadi bila hal itu merugikan orang lain atau merusak alam. (Adiwarman A. Karim, 2008: 35; 'Abd al-Hamid Barahimi, 1997; 32-33)

\section{Nubuwwah (Kenabian)}

Allah telah mengirimkan "manusia model" yang terakhir dan sempurna untuk diteladani sampai akhir zaman, Nabi Muhammad Saw. Sifat-sifat utama sang model yang harus diteladani oleh manusia pada umumnya dan pelaku ekonomi dan bisnis pada khususnya, adalah shiddiq (benar,jujur), amanah (tanggung jawab, kepercayaan, kredibilitas), fathanah (kecerdikan ,kebijaksanaan, intelektualitas) dan tabligh (Komunikasi, keterbukaan, pemasaran). (Adiwarman A. Karim, 2008: 38-40)

\section{Khilafah (Pemerintahan)}

Dalam Alquran, Allah berfirman bahwa manusia diciptakan untuk menjadi khalifah di bumi, (Q.S. 2:30) artinya untuk menjadi pemipin dan pemakmur bumi. Oleh karena itu, manusia pada dasarnya adalah sebagai pemimpin. Ini berlaku bagi 
semua manusia, baik dalam kapasitasnya sebagai individu, kepala keluarga, pemimpin masyarakat atau kepala Negara. Dalam Islam, pemerintah memainkan peranan yang penting dalam persoalan perekonomian. Peran sentralnya adalah dalam menjaga dan menjamin perekonomian agar berjalan sesuai dengan syari'ah (hukum Islam) dan memastikan supaya tidak terjadi pelanggaranterhadap hak-hak manusia. Hal ini dapat ditemukan dalam institusi Islam dikenal istilah Wilayah al-Hisbah, yaitu lembaga yang berfungsi sebagai perpanjangan tangan pemerintah dalam menyelesaikan persoalan yang menyangkut dengan ekonomi. (Adiwarman A. Karim, 2008 : 40-41)

\section{Ma'ad (hasil)}

Ma'ad secara harfiah ma'ad berarti "kembali". Karena kita semua akan kembali kepada Allah. Hidup manusia bukan hanya di dunia, tetapi terus berlanjut hingga alam setelah dunia (akhirat). Allah menandaskan bahwa manusia diciptakan di dunia untuk berjuang. Perjuangan ini akan mendapat ganjaran, baik di dunia maupun di akhirat. Perbuatan baik dibalas dengan kebaikan yang berlipat-lipat, perbuatab jahat dibalas dengan ganjaran. Implikasi nilai ini dalam kehidupan ekonomi dan bisnis misalnya diformulasikan oleh Iman Al-Ghazali yang menyatakan bahwa motivasi para pelaku bisnis adalah untuk mendapatkan laba. Laba dunia dan laba akhirat. Karena itu konsep prifit mendapat legitimasi dalam Islam. (Adiwarman A. Karim, 2008: 41-42)

\section{HUKUM EKONOMI ISLAM}

\section{Hakikat Hukum Ekonomi Islam}

Secara epistemologis, ekonomi Islam dibagi menjadi dua disiplin ilmu; Pertama, ekonomi Islam normatif yang disebut dengan sistem ekonomi Islam (al-nizham al-iqtishadi fi al-Islâm) dan positif yang diistilahkan dengan ilmu ekonomi Islam (al-'ilmu al-iqtishadi fi al-Islam). Ekonomi Islam normatif melingkupi studi tentang hukum-hukum syariah Islam yang berkaitan dengan urusan harta benda (al-mal), yang terdiri dari: kepemilikan (al-milkiyah), pemanfaatan kepemilikan (tasharruf fi al-milkiyah), dan (3) distribusi kekayaan kepada masyarakat (tauzi' al-tsarwah baina al-nas). Bagian ini dihasilkan melalui metode deduksi (istinbath) hukum dari al-Qur'an dan as-Sunnah. Sedangkan ekonomi Islam positif merupakan studi tentang konsep-konsep Islam yang berkaitan dengan urusan harta benda, khususnya yang berkaitan dengan produksi barang dan jasa. Bagian ini termasuk pemikiran universal, karena diperoleh dari fakta empiris, dengan menggunakan metode induksi (istiqra') terhadap fakta-fakta empiris 
dan hanya disyaratkan tidak boleh bertentangan dengan al-Qur'an dan Sunnah. (Hendri Hermawan Adinugraha, 2013: 56-57)

Dari keterangan di atas, maka kajian ekonomi Islam tidak dapat dipisahkan dengan fikih mu'amalat, yaitu hukum yang mengatur hubungan antara manusia dalam lapangan hartabenda (al-amwal), hak, dan pengelolaan harta (al-tasharruf) melalui transaksi (akad) dan lainnya. Secara ringkas ekonomi Islam meliputi: (1) benda dan kepemilikan, (2) persoalan hak dan halhal yang berhubungan dengannya, (3) perikatan atau akad yang berhubungan dengan kedua hal tersebut.

\section{Sumber Hukum Ekonomi Islam}

Sumber utama hukum Ekonomi Islam adalah al-Qur'an yang merupakan sumber asli dan abadi dari hukum Islam. Ia merupakan petunjuk dan bimbingan agama secara umum. Untuk itu ketentuan hukum untuk sebagian besarnya, tidak bersifat rinci, tetapi bisanya dalam bentuk kaidah-kaidah umum yang membutuhkan penalaran (akal) untuk memahaminya. Termasuk ketentuan yang mengatur tentang persoalan ekonomi, karena terkait dengan persoalan mu'amalah maka sangat tersusun dalam bentuk kaidahkaidah yang bersifat mujmal dan umum.

Sumber hukum kedua yang dipandang otoritatif setelah al-Qur'an adalah Sunnah, yaitu ajaran-ajaran
Nabi saw yang ditransformasikan lewat ucapan (qauli), perbuatan (fi'li) dan ketetapan (taqriri). (Zakariya alAnshari, t.t.: 85) Hanya saja, berbeda dengan al-Qur`an yang otentisitasnya dipandang valid, maka hadis tidak semuanya bernilai shahih, tetapi ada juga yang dipandang hasan bahkan dha'if. Untuk dapat dijadikan sebagai sumber hukum maka sunnah tersebut harus bernilai shahih dan minimal hasan. Sedangkan sunnah yang bernilai dha'if maka dipandang tidak otoritatif untuk dijadikan sebagai sumber hukum.

Sumber hukum ketiga adalah ijmak, yaitu kesepakatan semua ulama mengenai ketentuan atau hukum suatu kasus. (Abu Ishaq Ibrahim ibn 'Ali al-Syairazi, 1985: 47) Bahkan ada yang mengatakan bahwa ijmak itu tidak hanya kesepakatan ulama atau mujtahid bahkan ada yang mengatakan bahwa ijmak itu adalah kesepakatan semuat umat Nabi Muhammad saw. Untuk itu, tidak mengherankan jika tidak semua ulama menerima ijmak sebagaimana yang dirumuskan. Mazhab Hanbali misalnya, menolak konsepsi ijmak sebagaimana disebutkan di atas, karena ketidakmungkinan terjadinya ijmak seperti itu secara faktual.

Sumber hukum keempat adalah qiyas, yaitu sebagai bentuk perluasan ketentuan hukum yang telah disebutkan dalam al-Qur'an dan Sunnah, sehingga mencakaup kasus 
serupa yang tidak disebutkan dalam teks kedua sumber tersebut berdasarkan persamaan 'illah (ratio legis) antara kedua kasus tersebut.( AlZarkasi, t.t.: 206) Sehingga secara aplikatif dapat dikatakan bahwa qiyas adalah menganalogikan ketentuan kasus baru dengan kasus lama yang telah ditetapkan ketentuan hukumnya dalam nas. Misalnya menganalogikan keriadaan sebagai syaratnya sahnya dalam semua transaksi kepada akad jual beli.

Sejauh ini, keempat empat dalil hukum yang dapat dijadikan dasar dalam menetapkan hukum, yang telah diterima dan dijadikan sandaran oleh keempat mazhab hukuum Sunni. Di samping itu terdapat beberapa dalil lain yang juga dapat dijadikan dalil hukum Islam. Hanya saja validitasnya tidak disepakati oleh para ulama, tetapi hanya menjadika pegangan sebagian ulama. Sehingga sebgagian ulama menjadikannya dalil, semenara sebagian yang lain tidak. Di antara dalil-dalil itu adalah istihsan, maslahah mursalah, istishhab, sadd al-zari'ah, 'urf, qaul al-shahabi dan syar' man qablana.

\section{Mazhab-Mazhab Hukum Islam}

Mazhab secara etimologis berarti al-mu'taqad, (Ibn Manzur, 1990:. 394) yaitu pendirian yang dijadikan dasar atau landasan. Sedangkan secara terminologi menurut intelektual Hukum Islam adalah pendapat seorang yuris (imam) tentang hukum- hukum masalah ijtihadiyah.( AlNawawi, t.t.: 55) Bisa juga dikatakan sebagai paham atau aliran Hukum Islam yang terbentuk dari hasil ijtihad seorang mujtahid dalam usahanya memahami dan menggali hukumhukum dari sumbernya (al-Qur'an dan sunnah).( IAIN Syarif Hidayatullah, 1993: 214)

Dalam persfektif historis, membicarakan mazhab dalam periode awal akan membuka wacana kita tentang Mazhab Umar, Aisyah, Ibn Abbas dan sebagainya, sebagai hasil dari ijtihad fardi (individual). Pada periode ini semua mazhab dapat dibedakan menjadi dua madrasah, yaitu madrasah al-khulafa dan Madrasah Ahl al-Bayt. Atau disebut juga dengan madrasah umari dan madrasah 'alawi. Kelompok pertama yang dinisbahkan kepada Umar ibn Khattab pada akhirnya mengkristal menjadi kelompok sunni. Sedang kelompok kedua yang dinisbahkan kepada Ali ibn Abi Thalib pada akhirnya mengkristal menjadi aliran syi'ah.

Pada periode Umayyah, Madrasah al-Khulafa' terpolarisasi menjadi dua kelompok, yaitu Ahl alHadis (tradisonalis) dan Ahl al-Ra'y (rasionalis). Kelompok pertama merupakan representasi Imam Malik ibn Anas yang berpusat di Madinah, dengan karakteristiknya lebih mengutamakan sunnah dan meminimalisir intervensi logika (rasio). Sedangkan kelompok kedua 
yang merupakan representasi dari Imam Hanafi dan berpusat di Kufah, yang dicirikan dengan penggunaan akal lebih dominan dari pada pengunaan sunnah, melalui penganalisaan 'illat hukum (ratio legis) dan intensi legislasi (maqashid alsyari'ah).

Sementara itu Madrasah Ahl alBayt, akibat merginalisasi penguasa, menyebabkan kelompok ini tumbuh dan berkembang di bawah tekanan secara esoterisme dalam bentuk gerakan bawah tanah dalam mengikuti imam mereka. Konsekuensinya, mazhab ini kurang populer dalam komunitas Islam dan kurang mendapat tempat di hati masyarakat. Sehingga tidak mengherankan kalau mazhab ini hanya kita temukan di wilayah dan kawasan tertentu saja.

Dalam periode Umayyah ini madrasah-madrasah tersebut belum melahirkan pemikiran mazhab. Sedangkan pada periode Abbasiyah, Hukum Islam mengalami pertumbuhan dan perkembangan secara pesat. Sehingga periode tersebut dikenal sebagai periode pertumbuhan, penguatan dan pematangan pemikiran, meluasnya studi-studi ilmiah dan bermunculannya para mujtahid mutlak. Khususnya dalam bidang fiqh menurut 'Ali al-Sayis, setidaknya telah melahirkan tiga belas orang mujtahid mutlak yang berkarya dalam periode ini. Mereka adalah Sufyan ibn 'Uyaynah di Mekkah, Malik ibn Anas di Madinah, Hasan al-Basri di Basrah, Abu Hanifah dan al-Auza'i di Syam, Imam Syafi'iy dan al-Lais ibn Sa'd di Mesir, Ishaq ibn Rahawiyah di Naisabur, dan al-Zahiri dan Ibn Jarir di Baghdad.( Thaha Jabir al-Fayyad alUlwany, 1405 H.: 90) Jumlah ini tidak menafikan ulama-ulama lain yang juga berkarya namun tidak tercover dalam lintasan historis hukum Islam.

\section{a. Mazhab Hanafi}

Mazhab ini sebagai mazhab hukum yang tertua dikalangan sunni dan dinisbahkan kepada imam atau mujtahidnya yang bernama Imam Abu Hanifah atau populer juga dengan sebutan Imam Hanafi. Nama lengkap Imam Hanafi adalah Nu'man ibn Tsabit ibn Safi' al-Tamimy. Dilahirkan di Kufah pada tahun $80 \mathrm{H} / 699 \mathrm{M}$ dan wafat dalam usia 70 tahun di Baghdad pada tahun 150 H.( Abu Ishaq al-Syairazi, 1970: 86)

Imam Hanafi merupakan seorang yang berprofesi sebagai saudagar, yang juga pakar dalam bidang teologi dan hadis.( Hassan Ibrahim Hassan, 1989: 147) Namun akhirnya Imam Abu Hanifah lebih populer sebagai intelektual hukum Islam (fuqaha) yang bercorak rasional ketimbang sebagai seorang intelektual hadis.

Mazhabnya yang dikodifikasikan oleh muridnya 
Abu Yusuf (w 182 H) dan Muhammad ibn Hasan al-Syaibani (w 189 H) ini,( 'Athiyah Masyrifah, 1966: 51) mendasarkan pokokpokok fiqhnya kepada; al-Qur'an, Sunnah, ijma', pendapat para sahabat, qiyas, istihsan,'urf (tradisi setempat).(Sufi Husein Abu Thalib, 1995: 174-175) Mazhab ini menempatkan istihsan sebagai dalil yang khusus. Kemudian karena fiqh Mazhab Hanafi ini yang sangat bercorak rasional maka mazhabnya disebut mazhab hukum yang beraliran $r a^{\prime} y$.

Dalam bidang ekonomi mazhab ini telah melahirkan seorang tokoh populis dengan karya monumental sebagai buku rujukan pokok ekonmi Islam, yaitu Abu Yusuf dengan karya besarnya "Kitab al-Kharraj". Bahkan karya monumental ini dajadikan rujukan utama bagi pemerintah dalam mengeluarkan kebijakan dalam bidang perekonomian.(Fu'ad 'Abdullah al-'Umar, 2003: 50)

b. Mazhab Maliki

$$
\text { Mazhab yang bercorak }
$$
tradisional ini didirikan dan dinisbahkan kepada nama Malik ibn Anas. Dilahirkan di Madinah pada tahun $95 \mathrm{H}$ dan wafat pada tahun $179 \mathrm{H}$ juga di Madinah, dalam usian 84 tahun.(Abu Ishaq al-Syairazi, 1970: 68) Imam Malik merupakan seorang ulama yang sangat bercorak tradisional dan lebih mengutamakan penerapan Sunnah dan ijma' komunitas Madinah serta meminimalisir penggunaan rasio (logika).

Imam Malik dalam istinbat hukumnya -dengan mengunakan skala prioritas- bersumber kepada; al-Qur'an, Sunnah (mutawatir dan masyhurah), ijma' penduduk Madinah, fatwa sahabat, khabar ahad, qiyas, istihsan, istislah, sad alzari'ah, istishab dan syar' man qablana.( Muhammad Abu Zahrah, t.t.: 219-359)

Mazhab ini juga punya andil dalam menambah koleksi pembahasan ulama tentang persoalan ekonomi adalah buku Ibn Rusyd "Bidayah al-mujtahid wa nihayah al-muqtashid", terutama bab tentang "Jual Beli". (Fu'ad 'Abdullah al-'Umar, 2003: 54)

c. Mazhab Syafi'iy

Mazhab ini dinisbahkan kepada pendirinya yaitu Imam Syafi'iy. Nama lengkapnya adalah Muhammad ibn Idris ibn al-'Abbas ibn 'Usman ibn Syafi'iy ibn al-Syaib ibn 'Ubaid ibn 'Abd al-Yazid ibn Hasyim ibn 'Abd al-Muthalib ibn 'Abd al-Manaf. Dilahirkan di Gazza (sebuah kota dekat Lebanon) tahun $150 \mathrm{H}$ (yang bertepatan dengan tahun wafatnya Imam Hanafi dan wafat di Mesir pada tahun 204 $\mathrm{H}$,dalam usia 54 tahun. (Abu Ishaq al-Syairazi, 1970: 71) Imam Syafi'iy 
hidup di masa kekuasaan Abu Ja'far al-Mansur (Abbasiyyah).( Muhammad al-Khudari Bik, 1995: 140-141)

Imam Syafi'iyy pernah berguru kepada Imam Malik dan Muhammad ibn Hasan al-Syaibani (Hanafiyah). Sementara itu muridnya yang paling terkenal adalah Ahmad ibn Hanbal, yang dikemudian hari mendirikan Mazhab Hambali. Imam Syafi'iy merupakan pengarang al-Risalah, sebuah kitab yang menjadikannya sebagai pelopor dalam bidang usul fiqh sebagai metode dalam melakukan istinbat hukum.( 'Abd al-Wahhab Khallaf, 1990: 17)

Imam Syafi'iy yang populer dengan qaul al-qadim dan qaul aljadid-nya, dalam melakukan istinbat hukum, bersumber dengan skala prioritas- kepada; al-Qur'an, Sunnah, apabila tidak ditemukan dia memakai qiyas. Makna hadis yang diutamakan adalah zahir-nya. Dia menolak hadis munqati', kecuali riwayat Ibn al-Musayyab.(Thaha Jabir al-Fayyad al-Ulwany, 1405 H.: 95)

$\begin{array}{rrr}\text { Mazhab } & \text { Syafi'i } & \text { juga } \\ \text { memberikan } & \text { andil } & \text { dalam }\end{array}$
pengembangan pemikiran ekonomi Islam. Di antara karya menumental yang patut dikedepankan adalah buku "al-Rutbah fi Thalab alHisbah" karya Abu Hasan al-
Mawardi. (Fu'ad 'Abdullah al‘Umar, 2003: 55)

d. Mazhab Hanbali

Pendiri mazhab ini adalah Imam Ahmad ibn Hanbal. Nama lengkapnya adalah $\mathrm{Abu}$ 'Abdullah Ahmad ibn Muhammad ibn Hanbal ibn Hilal al-Syaibani. Lahir di Baghdad pada tahun $164 \mathrm{H}$ dan wafat pada tahun $241 \mathrm{H}$. (Abu Ishaq al-Syairazi, 1970: 91) Di antara gurunya yang paling terkenal adalah Imam Syafi'iy dan Abu Yusuf. Sedangkan diantara muridnya yang paling berperan mengembangakan mazhabnya di kemudian hari adalah anaknya Shaleh (w. $261 \mathrm{H}$ ) dan 'Abdullah (w. 290 H), Ahmad ibn Muhammad ibn Hani Abu Bakr al-Asrami (w. $261 \mathrm{H})$, Ibn Taymiyah dan lain sebagainya. ( Muhammad alKhudari Bik, 1995: 145)

Sumber ijtihadnya adalah alQur'an dan Sunnah secara tekstual dan meminimalisir pendekatan kontekstual dalam memahami kedua nas tersebut. Kalau tidak ada nas dia melihat kepada fatwa atau pendapat sahabat yang paling dekat kepada nas. Sesudah itu dia menggunakan hadis mursal dan da'if, selama tidak terdapat qaul sahabat, asar ataupun ijma' yang menyalahinya. Jika hadis mursal dan da'if tidak ditemukan, baru menerapkan qiyas. Imam Ahmad juga menggunakan sad al-zari'ah, 
(Thaha Jabir al-Fayyad al-Ulwany, 1405 H.: 96-97) menggunakan ijma', al-maslahah, istishab, dan hanya menggunakan qiyas dalam kondisi darurat. (Sufi Husein Abu Thalib, 1995: 180)

Dalam bidang ekonomi Islam mazhab ini juga telah melahirkan ulama yang terkemuka, yaitu Ibn Rajab. Pemikiran ekonominya dapat ditemukan dalam karya monumentalnya "al-Istikhraj li Ahkam al-Kharraj”. (Fu`ad 'Abdullah al-'Umar, 2003: 49)

\section{PENUTUP}

Ekonomi Islam dapat dilihat dari dua sudut pandang, yaitu sudut pandang akhlak yang akan melahirkan prinsip-prinsip ekonomi Islam dan \dari sudut pandang hukum yang akan melahirkan hukum ekonomi Islam. Untuk itu ekonomi Islm tidak berada dalam bidang ibadah, tetapi berada dalam kajian mu'amalah, yang membuka peluang untuk terjadi perubahan dan perkembangan sesuai dengan kebutuhan manusia, sepanjang tidak bertentangan dengan prinsip-prinsip Islam.

\section{KEPUSTAKAAN ACUAN}

'Abd al-Hamid Barahimi, al-'Adalah alIjtima'iyah wa al-Tanmiyah fi alIqtishad al-Islami, Markaz Dirasat al-wahdah al-'Arabiyah, Beirut, 1997

'Abd al-Wahhab Khallaf, 'Ilm Ushul alFiqh, Maktabah al-Da'wah Kairo, al-Islamiyah, 1990

'Athiyah Masyrifah, al-Qadha' fi alIslam, Syirkah al-Syarq alAusath, Ttp., 1966

Abu Ishaq al-Syairazi, Thabaqat alFuqaha', Dar al-Ra`id al-'Arabi, Beirut, 1970

Abu Ishaq Ibrahim ibn 'Ali al-Syairazi, al-Luma' fi Ushul al-Figh, Dar alKutub al-'Ilmiah, Beirut, 1985

Adiwarman A. Karim, Ekonomi Mikro Islam PT Raja Grafindo Persada, Jakarta, 2008

Al-Nawawi, al-Majma' Syarh alMuhazzab, Mathba'ah Salafiyah, Madinah, tt.

Al-Zarkasi, al-Bahr al-Muhith, dalam "al-Maktabah al-Syamilah"

Fu’ad 'Abdullah al-'Umar, Muqaddimah fi Tarikh al-Iqtishad al-islami wa Tatharruwihi, alMa'had al-Islami li al-Buhuts wa al-tadrib, IDB, 2003

Hassan Ibrahim Hassan, Sejarah Kebudayaan Islam, Alih Bahasa Djahdan Humam, Kota Kembang, Yogyakarta, 1989

Hendri Hermawan Adinugraha, "Norma dan Nilai dalam Ilmu Ekonomi Islam." Dalam Media 
Ekonomi \& Teknologi Imformasi, Muhammad al-Khudari Bik, Tarikh Vol. 21, Nomor 1 Maret 2013 Tasyri' al-Islami Dar al-Fikr,

IAIN Syarif Hidayatullah Jakarta, Beirut, 1995

Ensiklopedi Islam, DEPAG, Nazir Hammad, Qadhaya Fighiyah Jakarta, 1993 $M u^{\prime}$ ashirah fi al-Mal wa al-Iqtishad,

Ibn Manzur, Lisan al-'Arab, Dar alShadir, Beirut, 1990

Dar al-Qalam, damaskus, 2001

M.Umer Chapra, Islam dan Tantangan Ekonomi, Alih Bahasa: Ikhwan Abidin, Gema Insani Press, Jakarta, 2000

Muhammad Abu Zahrah, Imam Malik: Hayatuhu wa 'Ashruhu, Ara'uhu wa Fiqhuhu. Dar al-Fikr al-'Arabi, Ttp., tt.

Sufi Husein al-Thalib, Tathbiq alSyari'ah al-Islamiyah fi Bilad al'Arabiyah, Mathba'ah Jami'ah Qahirah, Kairo, 1995

Thaha Jabir al-Fayyad al-Ulwany, Adab al-Ikhtilaf fi al-Islam, alUmmah, Qatar, $1405 \mathrm{H}$

Zakariya al-Anshari, Ghayah al-Wushul fi Syarh Lubb al-Ushul, tp, Ttp., tt. 